\title{
Virtual Training On Competency Improvement Bank Mandiri Employees In Covid Pandemic 19
}

\author{
Riza Azizy1, Dedi Rianto Rahadi2
}

1,2,3,4 Department of Management, Faculty of Economic and Business, President University, Indonesia

\begin{abstract}
Training is a company strategy to improve employee performance competencies. However, in the current Covid 19 pandemic, companies cannot conduct training directly because of the government's rules to cdo work and study activities from home. During the Covid 19 pandemic, companies tried to develop employee performance skills, virtual training is one of the methods used to improve employee performance during the COVID-19 pandemic. Bank Mandiri use virtual training solutions to provide training for employees to maintain employee performance so that the company's goals could be achieved even in difficult circumstances such as the current Covid 19 pandemic. The study aims to determine whether virtual training has an effect on improving the performance of Bank Mandiri employees by using qualitative research to describe facts about an incident at Bank Mandiri and a situation that occurred during the COVID-19 pandemic. Data was collected using a survey method by distributing questionnaires to employee respondents. The results showed that the Virtual Training conducted by Bank Mandiri had a very good effect on improving the performance of Bank Mandiri employees.
\end{abstract}

\section{INTRODUCTION}

In a company, employee competency improvement is something that is continuously conduct to develop employees' abilities. Competence refers to the characteristics that underlie behavior that describe the motives, personal characteristics, self-concept, values, knowledge or skills bring by a person who is superior in the workplace (Spencer and Spencer, 1993).

During the current pandemic, it is very difficult for employees to conduct training because of health protocols that require all activities to do from home and must maintain a distance. This limitation has triggered the emergence of virtual training or online training, even though doing work from home increasing work competence can still be done. Competency improvement through virtual training is used as a solution for employees to develop their potential skills. The company has goals and objectives for the company to be able to obtain the maximum profit they want to achieve even though there are big challenges that must be faced, but with the challenges of the current pandemic the company is trying to continue to develop its human resources to achieve the company's targets.

The definition of training as defined by Pramudyo (2007: 16) is a learning process designed to change the performance of people in doing their jobs. What is meant in this case is that there are four things that must be considered, namely the training process, performance, training participants, and work. It must be understood that the training process refers to a change that must occur in the training participants. In the training process, poor performance is corrected in such a way as to get better. So that a set of tasks that have been waiting for can be done properly by workers who have attended the training.

Since the pandemic the employess should carry out their work and doing form home. The problem came up when company can not conduct the training while the company need to increase their performance and the employees need to improve their abilities, update their knowledge, update their information. It should be done in the interest and to achieve company's goal. The restrictions because of pandemic that makes vritual training become a solution for the 
company to still be able to conduct training from home for the employees, so that the employees still can make improvement for their performance.

\section{Definition of Virtual}

Based on virtual communication theory or so-called hyperpersonal communication (Walter: 1996: 5), namely communication with internet media which according to society social is more attractive when compared to direct communication. With the presence of virtual communication that is developing in human life, it is possible to produce a new environment which he calls a "global village". This can be interpreted, "when the world shrinks the world, the involvement of people in the lives of others will be higher". Virtual communication itself is part of the innovations that continue to be developed in new media (new media). The use of old media is felt to have many shortcomings so that humans innovate to make new media that can be used without any distance and time restrictions and at the same time can be an ineractive medium. Through virtual communication, users can provide feedback on what they see.

\section{Definition of Training}

Companies have an obligation to plan a training program for employees to improve their abilities and competencies needed in the workplace (Jie and Roger, 2006). Training can be provided through different methods such as coaching and monitoring, peer cooperation and participation by subordinates.

Training programs not only develop employees but also help organizations to make best use of them and support their competitive advantage. Sims (2006) emphasizes that training focuses on the current job while development focuses on employee preparation for the future of the company.

\section{Definition of Performance}

The results of a process that refer to and measured over a certain period of time based on the provisions or agreements that have been predetermined. According to Muhammad Zainur Roziqin (2010:41) performance is as the whole process works from individuals whose results can be used the foundation to whether the individual's work is good or otherwise. From some of the above understandings can be concluded that the performance is the result of quality work and the quantity achieved by the employee as a whole which can be used as a the foundation to determine whether the individual work either or Instead. Indicators for measuring the performance of Mangkunegara (2011:75): Leather Work, Quantity Work, Productivity, Initiatives, Cooperation, Responsibility.

\section{The Covid Pandemic 19}

The outbreak of a new pneumonia that started in Wuhan, Hubei Province, which then spread widely and rapidly to more than 190 countries and territories. This outbreak is named coronavirus disease 2019 (COVID19) which is caused by Severe Acute Respiratory Syndrome Coronavirus-2 (SARSCoV-19). The most common symptoms of COVID-19 are fever, fatigue, and dry cough. Some patients may experience aches and pains, nasal congestion, colds, sore throats or diarrhea. These symptoms are mild and occur gradually.

However, some people who are infected but do not show any symptoms and do not feel unwell. Most people (about $80 \%$ ) recover from the disease without the need for special treatment. About 1 out of every 6 people who get COVID-19 are seriously ill and have difficulty breathing. Older people, and those with medical problems such as high blood pressure, heart problems or diabetes, are more likely to get a serious illness. People with fever, cough and breathing difficulties should get medical attention.

According to the WHO, the COVID19 coronavirus spreads people through small droplets from the nose or mouth that spread when a person coughs or exhales. These droplets then fall onto objects touched by others. The person then touches the eyes, nose, or mouth. Based on current studies, covid-19 spread through free air has not been found.

\section{METHODS}

This research is a qualitative survey research. Sources of data from this study are Bank Mandiri employees who have conducted virtual training during the pandemic. The characteristics of the companies that are the subject are banking companies that continue to carry out work activities with a shift and work from home system. Data were collected in August 2020 and processed in September 2020. 
The data collection technique used a questionnaire technique where the respondents were 38 Bank Mandiri employees from various regions throughout Indonesia who participated in virtual training during the pandemic period held by Bank Mandiri.

\section{Research Instrument}

This study uses a questionnaire instrument for virtual training variables as a training and development medium and Employee Performance. Determine the effect of virtual training on employee performance during the Covid 19 period, it was carried out using a Likert scale. Likert scale is a scale used to measure attitudes, opinions, perceptions of a person or group of people about social phenomena. Each instrument answer item on the Likert scale has a gradient from very positive to very negative.

Table 1. Likert Scale

\begin{tabular}{cccccc}
\hline SBS & SB & B & S & B & BS \\
\hline 6 & 5 & 4 & 3 & 2 & 1
\end{tabular}

\section{Collecting Data Method}

Obtaining research results requires data and information that can support research. The researcher carried out several data collection steps, namely (1) Observation; (2) Interview; (3) Questionnaires; (4)and Literature.

\section{Population and Research Sample}

The population in this study were employees of Bank Mandiri throughout Indonesia who conducted a Virtual Expertise Training for Industrial Business Fast Moving Consumer Goods which was held on 5-6 August 2020 with a total of 38 employees. Referring to 38 people who meet the requirements, the questionnaires distributed are 38 questionnaires.

\section{RESULT AND DISCUSSION}

The purpose of this study is to assess whether the implementation of virtual training in the covid-19 pandemic period can be implemented properly and to know the advantages and disadvantages of the implementation of virtual training to improve the performance of Bank Mandiri employees
Analysis of the Application of Virtual Training in Improving the Competence of Bank Mandiri Employees

In order to make it easier to analyze, the respondent's responses to virtual training were presented by researchers in the form of a table as a whole as follows:

Table 2. Analysis of Respondents' Responses Regarding the Implementation of Virtual Training in Improving Bank Mandiri Employee Performance:

Table 2. Average Result of Quesionnare

\begin{tabular}{lll}
\hline $\begin{array}{l}\text { Achievement of } \\
\text { training objectives }\end{array} \quad 5.7 \quad$ Very good
\end{tabular}

Benefits of training

$\begin{array}{lll}\text { for smooth } & 5.7 & \text { Very good }\end{array}$

assignments

Additional knowledge acquired

\section{$5.7 \quad$ Very good}

\begin{tabular}{lcc}
\hline Training method & 5.5 & Very good \\
\hline $\begin{array}{l}\text { Content of the } \\
\text { material / module }\end{array}$ & 5,6 & Very good \\
\hline Duration of training & 5,4 & Very good \\
\hline $\begin{array}{l}\text { Internet Network } \\
\text { Completeness of } \\
\text { training }\end{array}$ & 5.1 & Very good \\
\hline $\begin{array}{l}\text { Presentation aids } \\
\text { facilities }\end{array}$ & 5.3 & Very good \\
\hline $\begin{array}{l}\text { Committee service } \\
\text { Information and }\end{array}$ & 5.7 & Very good \\
\hline $\begin{array}{l}\text { services during } \\
\text { training }\end{array}$ & 5.7 & Very good \\
\hline Time management & 5.7 & Very good \\
\hline Total & 66.3 & \\
\hline Average & 5,53 & Very good \\
\hline Source: PT Praba Cip & $D a y a$ & \\
\hline
\end{tabular}

Source: PT Praba Cipta Daya

So, seen from Table 2 it is known that virtual training as a training medium in a pandemic period carried out by Bank Mandiri for its employees can be said to be very good, because the average of all statements is 5.7 in the interval $5.1-5,9=$ Very Good 


\section{Discussion}

Permatasari and Hardiyan conclude that application of e-learning make a positive effect to employees performance (2018:07). The implementation of virtual training to increase competency resulting a very good work. The implementation of virtual training have a very good relationship to improve employees competency. Virtual training program can conduct in effective and effisien ways so that the company's goal can achieved even in a pandemic covid 19 situation. "It's a good move to conduct a training program using virtual learning method in pandemic Covid 19 situation" Choiriyah and Riyanto (2020:2).

\section{CONCLUSION}

Overall, the results obtained are that virtual training as a solution during the Covid 19 pandemic has doing well. This can be proven from the results of the questionnaire data processing, which shows that the basis for consideration of the application of virtual training all produces very good criteria. Evidenced by the results of the calculation of the analysis of respondents' statements regarding virtual training. Respondents' answers to each statement submitted as a whole produce very good criteria, namely with an average of 5.5 and it means that the qualifications on which the application of virtual training is very good in accordance with its value which is in the interval 5.1-5.9.

Virtual training design can adapt in pandemic covid 19 situation where all the activity have to be done from home. It become a solution for the company to conduct a training and supporting the prevention of covid 19 at the same time. So that the company still can create a superior and competitive employee.

\section{REFERENCES}

Anwar Prabu Mangkunegara, (2011). Manajemen Sumber Daya Manusia Perusahaan, Remaja Rosdakarya, Bandung

Choiriyah, Siti and Riyanto, Setyo, Desain Pelatihan Pada Masa Pandemi Covid19 (Studi Kasus Constructive Learning Pada Penyampaian Pembelajaran Virtual Learning) Vol.2, No.8, Universitas Mercubuana:2020.
Devito, Joseph , A. 1997. Human Communication. New York: Harper Collinc Colege Publisher.

Daryanto. 2010. Media Pembelajaran Peranannya Sangat Penting dalam Mencapai Tujuan Pembelajaran. Yogyakarta: Gava Media, pp.168.

Hasan, Iqbal. 2002. Metodelogi Penelitian dan Aplikasinya. Jakarta: Ghallia Indonesia.

Muhamad Zainur Roziqin, (2010). Kepuasan Kerja, Malang: Averroes Press

Mangkuprawira, Safri. 2007. Manajemen Sumber Daya Manusia. Bogor: Cetakan pertama, Ghalia Indonesia Miles, Matthew \& Huberman, A. Michael. 1992. Analisis Data Kualitatif: Buku Sumber Tantang Metode-Metode Baru. Jakarta:Universitas Indonesia Press, pp.153.

Noe, Raymond A. 2010. Employe Training and Development Fifth Edition. New York: mcgraw Hill, pp.55

Permata Sari, Indah and Hardiyan, Pengaruh E-learning Sebagai Media Pelatihan dan Pengembangan Terhadap Kinerja Karywan BCA KCU Tangerang Vol.07, No.01, Sisfokom:2018

Sinambela, Poltak, Lijan. 2012. Kinerja Pegawai. Yogyakarta: Geraha IImu, pp.6.

Stanley J. Baran, Pengantar Komunikasi Massa Melek Media dan Budaya (Jakarta: Erlangga, 2008), hlm.386 